\title{
Delivery of curcumin by directed self-assembled micelles enhances therapeutic treatment of non-small-cell lung cancer [Corrigendum]
}

Zhu WT, Liu SY, Wu L, et al. Int J Nanomedicine. 2017; 12:2621-2634.

On page 2623, under the heading 'Entrapment effciency (EE) and DL', the sentence "Acetonitrile/2.5\% acetic acid $(58 / 42, \mathrm{v} / \mathrm{v})$ was used as eluent at a flow rate of $1 \mathrm{~mL} / \mathrm{min}$ " should read "Acetonitrile $/ 0.25 \%$ acetic acid (58/42, v/v) was used as eluent at a flow rate of $1 \mathrm{~mL} / \mathrm{min}$ ".

On page 2623, under the heading 'Cellular uptake of CUR/mPEG-PLA micelles', first paragraph, the sentence "Subsequently, cells were stained with Hoechst 33258 for 5 minutes, subsequently washed with PBS and fixed with cold 4\% paraformaldehyde for 10 minutes" should read
"Subsequently, cells were fixed with cold 4\% paraformaldehyde for 10 minutes and stained with Hoechst 33258 for 5 minutes".

On page 2626, under the heading 'Cytotoxicity and cellular uptake of A549 cells', first paragraph, the sentence "Half maximal inhibitory concentration $\left(\mathrm{IC}_{50}\right)$ of CUR/ mPEG-PLA micelles at 48 hours $(30.18 \mu \mathrm{g} / \mathrm{mL})$ was lower than that of free CUR $(36.69 \mu \mathrm{g} / \mathrm{mL})$ " should read "Half maximal inhibitory concentration $\left(\mathrm{IC}_{50}\right)$ of CUR/mPEG-PLA micelles at 48 hours $(19.27 \mu \mathrm{mol} / \mathrm{L})$ was lower than that of free CUR (27.02 $\mu \mathrm{mol} / \mathrm{L})$ ".

On page 2627, Figure 3, an incorrect image was given as Figure $3 \mathrm{~B}$. The correct Figure $3 \mathrm{~B}$ is presented below.

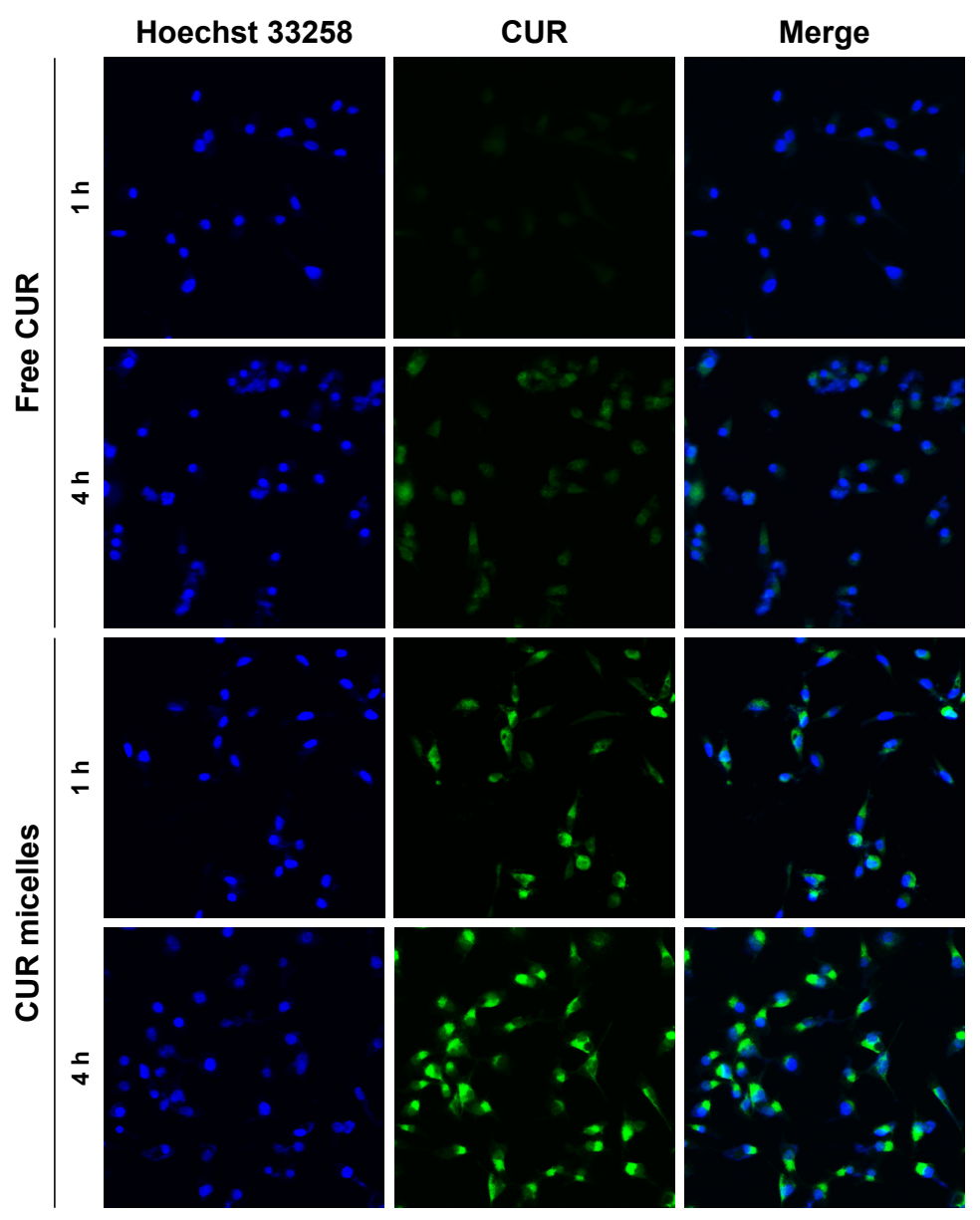

Figure 3 Cytotoxicity studies and cellular uptake assay of CUR micelles. 
On page 2629 , under the heading 'In vitro antiangiogenic activity of CUR/mPEG-PLA micelles', last sentence, the sentence "CUR/mPEG-PLA micelles had a lower $\mathrm{IC}_{50}$ (31.39 $\mu \mathrm{g} / \mathrm{mL})$ than free CUR $(43.02 \mu \mathrm{g} / \mathrm{mL})$ " should read

\section{Untreated}

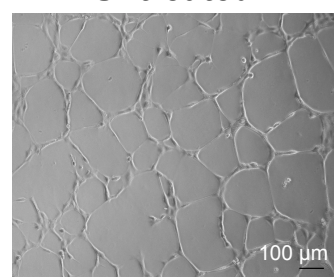

Blank micelles

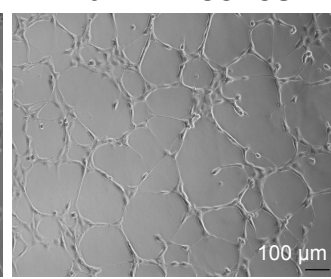

"CUR/mPEG-PLA micelles had a lower $\mathrm{IC}_{50}(15.59 \mu \mathrm{g} / \mathrm{mL})$ than free CUR $(26.05 \mu \mathrm{g} / \mathrm{mL})$ ".

On page 2631, Figure 7, an incorrect image was given as Figure 7A. The correct Figure 7A is presented below.
Figure 7 CUR micelles induced cytotoxicity and inhibited tube formation, migration and invasion of HUVECs in vitro.

\section{Publish your work in this journal}

The International Journal of Nanomedicine is an international, peerreviewed journal focusing on the application of nanotechnology in diagnostics, therapeutics, and drug delivery systems throughout the biomedical field. This journal is indexed on PubMed Central,

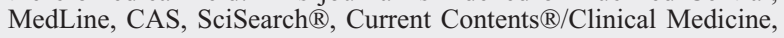

\section{Free CUR}

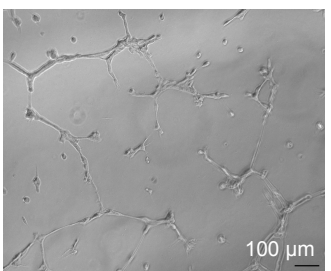

CUR micelles

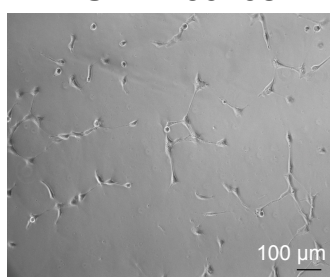

Journal Citation Reports/Science Edition, EMBase, Scopus and the Elsevier Bibliographic databases. The manuscript management system is completely online and includes a very quick and fair peer-review system, which is all easy to use. Visit http://www.dovepress.com/ testimonials.php to read real quotes from published authors. 